\title{
HOW TO PRESERVE AND INCREASE OIL AND GAS RESOURCES OF SIBERIA
}

\section{$\therefore$. пив лов \\ N. P. Zapivalov}

цион льный исследов тельский омский политехнический университет, г. омск нститут нефтег зовой геологии и геофизики им. . . рофимук

$$
\text { , 2. овосибирск }
$$

лючевые слов : нефтег зовые ресурсы ибири; недропользов ние; ктивн я ре билит иия месторождений

Key words: oil and gas resources of Siberia; subsoil; active rehabilitation fields

ибирь-это велич йщее бог тство оссии и з логее бл гополучия. ы еще поверхностно зн ем, что он в себе т ит. год ми будет выявлено очень и очень многое. оэтому мы должны дум ть,

$\kappa \kappa н$ м лучше все это выявить и сберечь.

epux, 1984 2.

икличность, осложненн я фр кт льными явлениями, флукту цией, бифурк цией, т кже природными и техногенными к т строф ми, является фунд мент льным принципом p звития и функциониров ния природных систем. менно это обеспечив ет периодическое уг с ние и восст новление многих жизненных процессов. к утвержд л философ . «природ д же в состоянии х ос может действов ть только пр вильно и сл женно».

римером может служить д же земледелие. древнейших времен известн методик восст новления и повышения плодородия почвы с помощью т к н зыв емой «п ровой системы»: 
отдельные поля ост вляют нез сеянными (н «отдых») для восст новления плодородия. еще цит (I в. н. э.) пис л, что герм нцы для посев р стений к ждый год меняют поля.

ходные мех низмы проявляются во всех природных систем х, включ я человеческий орг низм (циклы жизни). н логичные принципы применимы к восст новлению и обновлению выр бот нных месторождений нефти и г 3 . цепции.

сть много ф ктов, которые не вписыв ются в кл ссические нефтегеологические кон-

- $\quad$ нтересные д нные были получены в блоке $330 \mathrm{H}$ полигоне у побережья уизи ны, где р сположено гиг нтское месторождение ексик нского з лив джин йленд [1]. результ те сейсмор зведки, выполненной дв жды (1985 и 1988 гг.), уст новлен оч гов я изменчивость п р метров нефтен сыщенности и движения флюидов. омплексными исследов ниями уст новлено, что д же 3 короткий период н блюдений отмечено увеличение углеводородных м сс 3 счет ктивных современных процессов их обр зов ния. тмечено увеличение легких фр кций в нефтях.

- есторождение « игбой» в ндии (um $m$ c $c$ м $)$ т кже р зр б тыв ется уже более 100 лет.

- $\quad$ ебелинском г зовом месторождении н кр ине подсчит нные з п сы д вно отобр ны, но до сих пор добыв ют г з. тбор компенсируется декв тным притоком глубинного г з [2].

- звестны случ и рекордно длительной эксплу т ции нефтяных скв жин. двух месторождениях, $\mathrm{p}$ сположенных $н$ гр нице рузии $и$ бх зии, эксплу тируются месторождения с конц XIX век и до сих пор д ют притоки нефти.

оссии н блюд лись н логичные явления.

- предел х огромного ом шкинского месторождения в $m$ pcm не, уже обводненного н $86 \%, 140$ р сконсервиров нных скв жин вновь д ли нефть [3]. многие из них опять фонт нируют!

- еченской еспублике многие высокообводненные скв жины, н которых перед н ч лом войны осуществлялся форсиров нный отбор, и добыч п д л, н ч ли д в ть нефть: то есть в течение 4 лет простоя произошло переформиров ние 3 лежей. ник льное явление н блюд ется в последние годы в р йон х $\mathrm{T}$ рогрозненского и ктябрьского промыслов: первые мелкие скв жины глубиной до сотен метров (песч ники неоген ) ст ли выс чив ть нефть н дневную поверхность (через з трубное простр нство). ст точн Я нефть всплыв ет в кровлю пл ст и н чин ется формиров ние вторичных з лежей нефти.

- $\quad$ ряде месторождений $n$ дной ибири т кже з фиксиров н пульсирующий режим нефтедобычи в скв жин х [3].

бновленные процессы нефтег зообр зов ния отмеч ются во многих регион х мир . ыстрое и необр тимое истощение месторождений возможно лишь т м, где $p$ зр ботк месторождений осуществляется н сверхкритическом режиме.

ч говые процессы генер ции и формиров ния (или переформиров ния) 3 лежей, по мнению современных исследов телей [1, 4-5], происходят дост точно быстро.

оскольку док 3 н геологическ я молодость месторождений и периодическ я восполняемость их 3 п сов нефтью и г зом, н пр шив ется вывод, что счит ющиеся выр бот нными месторождения со временем могут вновь ст новиться объект ми нефтедобычи.

тим исследов ниям много р бот посвятил . . широв ${ }^{1}$. о его мнению [6], выводы о геологически молодом возр сте 3 лежей нефти и г $з$ имеют большое пр ктическое зн чение.

примере многих месторождений м рской обл сти им было уст новлено, что при их р 3p ботке $з$ п сы нефти в них восст н влив лись в объем х, д же превосходящих первон ч льные. этому приходилось их переутвержд ть в сторону увеличения, иногд д же трижды.

т к, люб я з лежь углеводородов - жив я открыт я систем , способн я к с мовосст новлению в относительно короткое время.

тот вывод особенно в жен для п дной ибири, где р зр ботк нефтяных месторождений продолж ется уже 50 лет.

л вн я нефтян я «житниц » оссии - это территория нты- нсийского втономного округ ( гр ), где открыто 465 месторождений углеводородного сырья, из которых более 250 н ходятся в р зр ботке. десь добыв ют более половины всей российской и $7 \%$

1 . . широв (1912-2001) - выд ющийся ученый, известный нефтяник, почетный к демик , д. г.- м. н., з служенный деятель н уки и техники, , уре $m$ енинской премии. первых дней еликой течественной войны он был в ряд х действующей рмии жного фронт, нк нуне з щитив к ндид тскую диссерт цию по нефтег зоносности « торого ку». рг низов лв н ч ле 60-х годов созд ние новой блоковой системы $p$ зр ботки, резко повыш ющей нефтеотд чу пл стов. ветлой $n$ мяти е миля екирович широв посвящ ется эт $\mathrm{cm}$ тья. 
мировой добычи нефти (третье место после и $\quad$ удовской $\quad \mathrm{p}$ вии). пеци листы из юмени утвержд ют, что здесь уже добыто более 10 млрд тонн нефти. то $5 \%$ от мировой н копленной добычи. ля этого потребов лось пробурить 370 млн метров горных пород, построить и ввести в эксплу т цию 158 тысяч скв жин. ыр ботк 3 п сов $\mathrm{ABC}_{1}+\mathrm{C}_{2}$ сост вил $48 \%$, то есть в недр х ост ется еще 11 млрд тонн [7].

ч лось интенсивное снижение добычи. ногие крупные месторождения н ходятся н третьей или четвертой ст дии р зр ботки. ких месторождений н считыв ется 80, среди них уник льные и крупные месторождения: линское, едоровское, тинское, жно- ургутское и монтовское. еобходимо отметить высокую обводненность пл стов (более $90 \%$ ).

к 3 нные ст дии р зр ботки являются н иболее трудным и продолжительным периодом. о именно в этих месторождениях сосредоточены большие объемы ост точных утвержденных 3 п сов нефти. кое положение возникло из-з многолетней погони 3 большой нефтью и сверхприбылями. тветственность 3 сложившееся положение дел лежит не только н недропользов телях. осуд рство, к к собственник недр, должно опер тивно отслежив ть текущую ситу цию и осуществлять жесткий контроль.

ля испр вления сложившейся ситу ции необходимо нез медлительно н ч ть широком сшт бное внедрение принципи льно новых технологий, включ я упр вляемые ре билит ционные циклы н месторождениях третьей и четвертой ст дии р зр ботки с целью увеличения конечной нефтеотд чи.

одобн я ситу ция сложил сь в омской и овосибирской обл стях.

н стоящее время следует сосредоточиться н р цион льной р зр ботке действующих месторождений с целью щ дящей выр ботки ост точной (трудноизвлек емой) нефти (ImprovedOilRecovery). ля д льнейших р бот н т ких месторождениях необходимо привлечение новых м тери льных и денежных ресурсов, нужны иннов ционные технологии и оборудов ние, изготовленное по индивиду льному з к зу.

сли это не сдел ть, то огромные м ссы утвержденных ост точных 3 п сов нефти ост нутся в недр х п дной ибири до следующих «новых» открытий уже р нее открытой нефти.

ефтяное недропользов ние: к ким ему быть?

еловеческие потребности т к необъятны и т к стремительно увеличив ются, что природ с трудом выдержив ет н грузки. ож луй, яркой иллюстр цией является то, к к неудержимо увеличив ется добыч углеводородов н суше и н море в р зных регион х. о существу, пл нет емля ст л огромным нефтяным полигоном.

верхинтенсивн я выр ботк легкодоступных 3 п сов нефти способствует быстрому истощению месторождений. о природн я флюидон сыщенн я систем (з лежь нефти) способн восполнять объемы 3 п сов в процессе «отдых »и ре билит ционного период (ч сто вынужденного).

д ч состоит в р зумном, н учно обоснов нном использов нии ре билит ционных циклов. еобходимость проведения очередного ре билит ционного цикл можно определить по величине депрессии в процессе р зр ботки месторождения. сли депрессия н пл ст $\left(P={ }_{n л}-{ }_{3}\right.$ б) превыш ет 5-8, это зн чит, что пл стов я флюидон сыщенн я систем достигл критического порог . ледов тельно, этой системе необходим отдых ре билит ционный цикл. озможно, этот цикл может быть «оч говым». ритическое состояние системы можно определять и по другим п р метр м. $\quad$ к кой-то степени это ср внимо с р ботой человеческого сердц и жизненными цикл ми орг низм .

ледует з метить, что ре билит ционный цикл - это не просто отдых, ост новк системы. еобходимо предусмотреть методы и технологии ктивной ре билит иии. тобы достичь эффективного и быстрого результ т - восполнения ктивных 3 п сов хотя бы в приз бойной зоне и увеличения продуктивности скв жины, нужны иннов ционные методы и технологии (к к в медицине).

документ х лицензиров ния, проект х $\mathrm{p}$ зр ботки и в долгосрочных прогр мм х недропользов ния должн быть обяз тельно предусмотрен необходимость ре билит ционных циклов. ти спекты нефтяного недропользов ния обяз тельно должны быть 3 креплены 3 конод тельно. олжен быть введен порядок, учитыв ющий з коны природы.

вьводы

- $\quad$ п дной ибири уже сейч с необходимо осуществить выборочную ревизию прост ив ющих м лодебитных и нер бот ющих скв жин, включ я и н гнет тельные, с обяз тельным повтором исследов ния пл стов, получением и . основе флюидодин мического н лиз реш ть вопросы о д льнейшей судьбе к ждой отдельной скв жины.

- еобходимо предусм трив ть периодические консерв ции объектов, включ я при необходимости целые зоны и месторождения. ужно счит ть н учно обоснов нным, что период ктивной ре билит ции обеспечив ет не только рел кс цию фильтр ционно- 
емкостных свойств пород, но и восст новление энергетического потенци л флюидон сыщенных систем. од ктивной ре билит цией подр зумев ется не простой «покой», допустимое воздействие н систему (лечение).

- $\quad$ ля р зр ботки н учно обоснов нных методов эксплу т ции нефтяных месторождений с использов нием ре билит ционных циклов необходим нефтяной н учноисследов тельский и н учно-обр зов тельный олигон федер льного или междун родного уровня. го можно созд ть н б зе овосибирских нефтег зовых месторождений в еверном р йоне.

- своение месторождений н сб л нсиров нном р вновесии в течение более длительного срок , чем принято по сегодняшним форсиров нным ст нд рт м, д ст больший сумм рный эффект. итоге это приведет к существенной экономии труд и к пит л .

- резвыч йно в жны экологические спекты. еобходимо з ботиться о здоровье нефтяного пл ст

писок литер туры

1. пив лов . ., опов . . люидодин мические модели з лежей нефти и г 3 . - овосибирск: ео, 2003. $-198 \mathrm{c}$.

2. киров . ов я жизнь скв жин-ветер нов: р сконсерв ция ст рых месторождений может ст ть новым источником нефти // оссийск я г зет № 6011 от 19 февр ля 2013 г.

3. услимов . ., лумов . ., ург лиев . . и др. ефтяные и г зовые месторождения - с мор звив ющиеся и постоянно возобновляемые объекты // елогия нефти и г з . - 2004. - № 1. - . 43-49.

4. пив лов . ин мик жизни нефтяного месторождения // звестия омского политехнического университет . - 2012. - .321. - № 1. - .206-211.

5. пив лов . . ефтег зов я геология: р дигмы XXI век // роблемы геологии и освоения недр: борник н учных трудов ХІ междун родного симпозиум им. к демик . . сов студентов и молодых ученых. омск: зд-во омский политехнический университет. $-2007 .-$. 766.

6. широв . ., оргест . ., рев . . боснов ние причин многокр тной восполнимости з п сов нефти и г 3 н р зр б тыв емых месторождениях м рской обл сти // звестия м рского н учного центр . - 2000.№ 1. - .166-143.

7. p нч . ., итроф нов . . ерспективы нефтедобычи и н лиз р зр ботки месторождений

гры с позиции их ст дийности // еология и нефтег зоносность п дно- ибирского мег б ссейн (опыт, иннов ции): м тери лы 9-й еждун родной н учно-технической конференции, посвященной 100-летию со дня рождения ротоз нов . . (10-11 дек бря 2014 г.). - юмень: юм , 2014. - . 1 ( урение и р зр ботк нефтяных и г зовых месторождений). - . 165-171.

\section{ведения об втор $x$}

пив лов икол й етрович, д. г.-м. н., профес сор, цион льный исследов тельский омский поли технический университет, г. омск; нститут нефтег зовой геологии и геофизики им. . рофимук

2. овосибирск, тел. 8(383)3332895, e-mail: ZapivalovNP@ipgg.sbras.ru
Information about the authors

Zapivalov N. P., Doctor of Geology and Mineralogy, Professor, Tomsk Polytechnic University, Tomsk Institute of Petroleum Geology and Geophysics A. A. Trofimuk SB RAS, Novosibirsk, phone: 8(383)3332895, e-mail: ZapivalovNP@ipgg.sbras.ru 